\title{
MODERN TECHNIQUES OF CERVICAL INSTRUMENTATION IN IMMATURE SKELETON: VIABILITY ASSESSMENT
}

\author{
TÉCNICAS MODERNAS DE INSTRUMENTAÇÃO CERVICAL NO ESQUELETO IMATURO: \\ AVALIAÇÃO DA VIABILIDADE
}

\section{TÉCNICAS MODERNAS DE INSTRUMENTACIÓN CERVICAL EN EL ESQUELETO INMADURO: EVALUACIÓN DE LA VIABILIDAD}

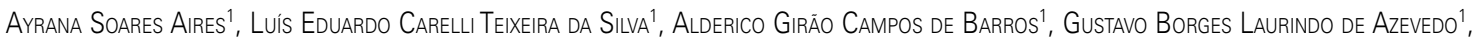
Cleiton Dias NAVES ${ }^{1}$

1. Instituto Nacional de Traumatologia e Ortopedia (INTO), Rio de Janeiro, RJ, Brazil.

\begin{abstract}
Objective: This study describes the use of materials for modern cervical instrumentation, evaluating its viability in children and adolescents, and the techniques used in different cases. The efficacy of the techniques was analyzed through improvement of pain, maintenance of cervical range of motion, recovery of craniocervical stability, bone consolidation, and spinal stenosis in the postoperative follow-up. Method: Retrospective study of the clinical and radiological parameters of 27 patients aged two to 16 years with cervical spine diseases. Results: Two patients had chronic dislocation in C1-C2, one had congenital axis spondylolisthesis, two had congenital dislocation in C1-C2, three had tumors, one had kyphosis after laminectomy, one had post-infection kyphosis, one had fracture, 11 were syndromic with instabilities, and five had congenital cervical scoliosis. As to surgical approaches, two patients were transorally operated, three by anterior approach, 15 by posterior approach, two by anterior and posterior approaches, and five were treated in three stages (anterior, posterior and anterior approaches). Regarding the technique of cervical stabilization, seven patients were treated by Goel-Harms technique, two received Goel's facet distraction, and three, Wright translaminar screws. There were complications in four cases. Two patients in the instrumentation of $\mathrm{C} 1$ lateral mass due to poor positioning, one with cerebrospinal fluid fistula and one with surgical wound infection. Conclusion: Modern cervical instrumentation in pediatric patients is a safe and effective technique for the treatment of cervical instability.
\end{abstract}

Keywords: Spine; Pediatrics; Instrumentation.

\section{RESUMO}

Objetivo: Este trabalho descreve o uso de materiais para instrumentação cervical moderna, avaliando sua viabilidade em crianças e adolescentes e as técnicas empregadas em diferentes casos. A eficácia das técnicas foi analisada através da melhora da dor, manutenção do arco de movimento, recuperação da estabilidade crânio-cervical, consolidação óssea e estenose de canal medular no seguimento pós-operatório. Método: Estudo retrospectivo dos parâmetros clínicos e radiológicos de 27 pacientes entre dois e 16 anos com doenças da coluna cervical. Resultados: Dois pacientes tinham luxação crônica em C1-C2, um tinha espondilolistese congênita do áxis, dois tinham luxação congênita C1-C2, três tinham tumores, um apresentou cifose pós-laminectomia, um tinha cifose pós-infecção, um tinha fratura, 11 eram sindrômicos com instabilidades e cinco tinham escoliose congênita. Quanto às vias de acesso, dois foram abordados por via transoral, três por via anterior, 15 por via posterior, dois por via anterior e posterior e cinco foram tratados em três etapas (anterior, posterior e anterior). Com relação à técnica de estabilização cenvical, em sete foram utilizadas técnica de GoelHarms, em dois, distração facetária de Goel e em três, parafusos translaminares de Wright. Houve complicações em quatro casos, dois pacientes na instrumentação da massa lateral de C1 por posicionamento inadequado, um com fístula liquórica e um com infecção da ferida operatória. Conclusão: A instrumentação cervical moderna em pacientes pediátricos é uma técnica segura e eficaz para o tratamento de instabilidade cervical.

Descritores: Coluna vertebral; Pediatria; Instrumentação.

\section{RESUMEN}

Objetivo: Este trabajo describe el uso de materiales para instrumentación cervical moderna, evaluando su viabilidad en niños y adolescentes y las técnicas empleadas en diferentes casos. La eficacia de las técnicas fue analizada a través de la mejora del dolor, mantenimiento del rango de movimiento, recuperación de la estabilidad cráneo-cenvical, consolidación ósea y estenosis del canal medular en el seguimiento postoperatorio. Método: Estudio retrospectivo de los parámetros clínicos y radiológicos de 27 pacientes entre dos y 16 años con enfermedades de la columna cenvical. Resultados: Dos pacientes tenían luxación crónica en C1-C2, uno tenía espondilolistesis congénita del áxis, dos tenían luxación congénita C1-C2, tres tenía tumores, uno presentó cifosis post-laminectomía, uno tenía cifosis post-infección, uno tenía fractura, 11 eran sindrómicos con inestabilidades y cinco tenían escoliosis congénita. En cuanto a las vías de acceso, dos fueron abordados por vía transoral, tres por vía anterior, 15 por vía posterior, dos por vía anterior y posterior y cinco fueron tratados en tres etapas (anterior, posterior y anterior). Con respecto a la técnica de estabilización cervical, en siete se utilizó la técnica de Goel-Harms, en dos, distracción facetaria de Goel y en tres, tornillos translaminares de Wright. Se observaron complicaciones en cuatro casos, dos pacientes en la instrumentación de la masa lateral de C1 por mal posicionamiento, uno con fístula de líquido cefalorraquídeo y uno con infección de la herida operatoria. Conclusión: La instrumentación cervical moderna en pacientes pediátricos es una técnica segura y eficaz para el tratamiento de la inestabilidad cenvical.

Descriptores: Columna vertebral; Pediatría; Instrumentación. 


\section{INTRODUCTION}

Lesions that affect the cervical spine in children and adolescents are relatively rare, however, when present, they pose a challenge due to complexity of the treatment and the possibility of catastrophic complications.

For many years, due to the limited availability of materials and biomechanical knowledge, many lesions were treated conservatively or using in situ arthrodesis techniques or fixations with sublaminar wires, which require the use of complementary techniques, such as external fixation. However, this type of treatment had the following consequences: high rates of pseudoarthrosis, loss of surgical correction with subsequent deformities, as well as additional morbidity attributed to the halo-vest and revision surgeries. ${ }^{1}$

Pedicle screws are biomechanically superior to other systems of vertebral stabilization and are considered the gold standard for thoracic and lumbar spine stabilization. ${ }^{2}$ Although the viability and mechanical advantages of pedicle screws in the cervical spine of adults has been demonstrated, their use in the cervical spine of patients with skeletal immaturity has not gained much popularity. ${ }^{3,4}$ This is due to the small dimensions of the pedicle, the ossification volume, fear of injury to neurovascular structures, as well as the variable anatomy of the vertebra. ${ }^{5}$

Several biomechanical studies have shown that pedicle screws offer better fixation than lateral mass screws. Their relative pullout strengths in two studies were $1214 \mathrm{~N}$ vs. $332 \mathrm{~N}(13)$, and $667 \mathrm{~N}$ vs. $355 \mathrm{~N}(14){ }^{6}$

Reduced bone and ligament structures and anatomical variations associated with cervical abnormalities resulting from syndromes complicate the approach and restrict the use of internal fixation. Cervical lordosis in children can limit growth potential and cause secondary deformity.

A broad spectrum of diseases can lead to an indication of cervical arthrodesis in children, whether for instability or compression. Among them, congenital and acquired anomalies stand out. Examples of acquired abnormalities are inveterate cervical dislocation, tumors, post-traumatic and post-infection kyphoses, and Grisel's syndrome. ${ }^{7}$

Congenital conditions observed in our study included congenital scoliosis from hemivertebrae, the absence of the posterior arch of $\mathrm{C} 1$, and congenital hangman fracture.

Indication for fusion include acute diseases where the disease is at a critical stage and intervention is essential (fractures, luxations, tumors), as well as rapidly progressing diseases, where evolution to instability is unpredictable. All treatments aim to resolve the disease and achieve stabilization of the cervical spine. In tumors, the primary treatment objectives are radical excision and stabilization of the cervical spine. Cervical tumors are less frequent in pediatric patients than in the adult population.

ervical arthrodesis should achieve spinal stabilization in order to prevent both neurological lesions and secondary compensatory deformities.

\section{METHODS}

This study was approved by the INTO Institutional Review Board (046/2016). We accessed the Instituto Nacional de Traumatologia e Ortopedia database for the previous 10 years, from January 2006 to December 2016, as well as the medical records of external patients, totaling 27 patients. Because this was a retrospective study, the informed consent form was not required. We identified patients who had undergone modern cervical instrumentation during this period and had a follow-up of at least eight years. The inclusion criteria considered were a minimum of two years of follow-up, patients less than or equal to 16 years of age who had undergone modern cervical instrumentation. Exclusion criteria were in situ arthrodesis, use of sublaminar wires, and patients older than 16 years of age.

Our analysis of the medical records yielded 27 patients between two and 16 years of age, with an average age of eight years, 17 of whom were female and 10 of whom were male, with an average follow-up of six years after modern cervical instrumentation. The selection and review of the records was based on the age of the patient and on their having been submitted to modern cervical instrumentation.

Radiographic evaluations included simple AP, lateral, and transoral radiographs of the cervical spine in diseases of the upper cervical spine and AP and lateral radiographs for diseases of the subaxial cervical spine. Computed tomography was used in axial cuts and sagittal and coronal reconstructions to measure the vertebral structures and to analyze the viability of instrumentation, in addition to postoperatively control the correct positioning of the implants.

Angiotomographies were used in cases of congenital malformation of the craniovertebral junction to study the path and possible anomalies of the vertebral artery.

Magnetic resonance was used to evaluate cases of malformation, neurological deficit, and tumors.

Posterior approach instrumentation of the subaxial cervical spine was performed using lateral mass screws.

In the upper cervical spine, Goel-Harms techniques were used for the instrumentation of $\mathrm{C} 1$ and $\mathrm{C} 2$. When the diameter of the lateral mass, pars interarticularis, and of the pedicle of C2 were less than $3.5 \mathrm{~mm}$ the progressive pedicle expansion technique using drills and cutters was performed, as is done in the lumbar spine of immature skeletons. In a recent study, Rinella et al. demonstrated in the cadaver of a 9-year-old male pre-adolescent that the pedicle can be expanded using successive pedicle screws reaching diameter of up to $8.5 \mathrm{~mm}$. The interior and exterior diameters of the dilated screws increased the original diameters by $74 \%$ and $24 \%$, respectively. ${ }^{8}$

For the anterior cervical spine, when a corpectomy was necessary, a mesh-type cage with a diameter proportional to the vertebral body of the patient was used for the reconstruction of the anterior spine.

In cases in which complementary stabilization was required, we used adult cervical spine locking plates in children older than 10 years of age. In children less than 10 years of age, or with reduced vertebral latero-lateral diameter, we used mini cranio-maxillofacial osteosynthesis plates. (Figure 1)

For the anterior (transoral) instrumentation of C1-C2 a Harms T-plate, customized for the age of the patient, was used.

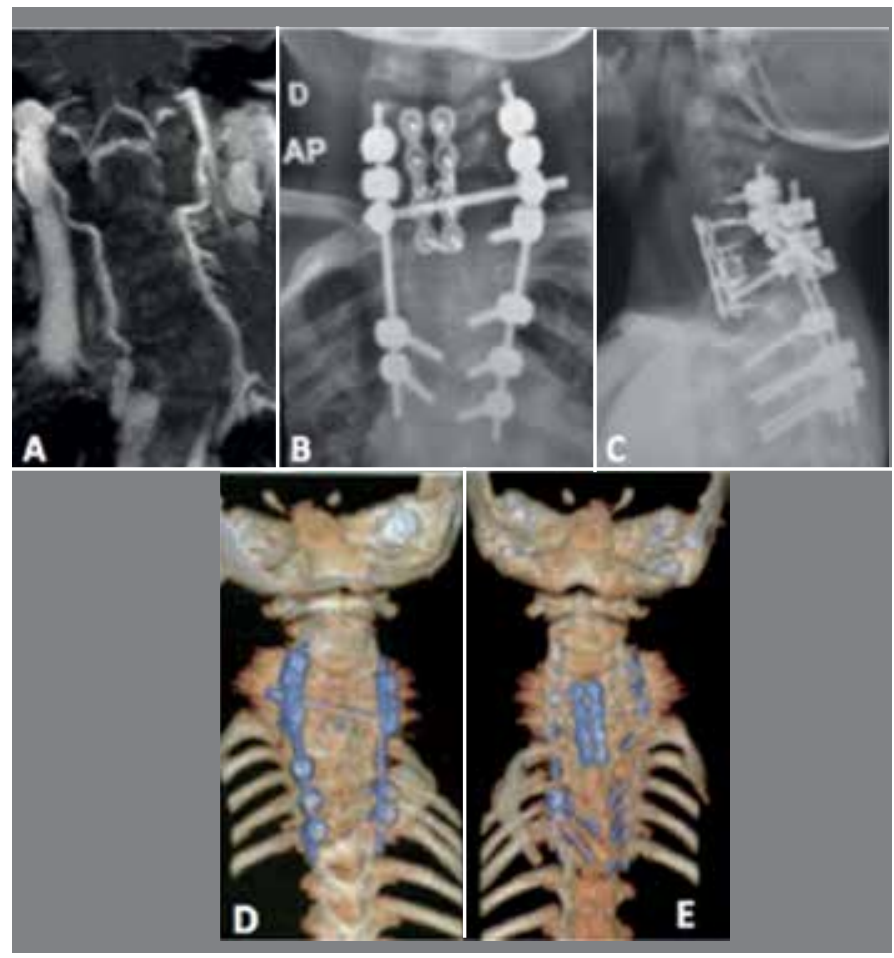

Figure 1. Use of CMF plate and lateral mass screws following cervical hemivertebral resection. (A) Preoperative NMR Image; (B) Postoperative AP X-Ray; (C) Postoperative lateral X-Ray; (D) Postoperative CT; (E) Postoperative CT. 
At the C2 level, we used laminar screws in some cases, according to the technique described by Wright, in the case of occurrence of a widened artery groove or anomaly of the same. ${ }^{9}$ (Figure 2)

For instrumentation of the occiput, a technique of plates and screws placed in the suboccipital region, similar to that used in adults, was performed. ${ }^{16}$

Posterior approach cages were used in one patient with Goel C1-C2 facet joint distraction. ${ }^{10,11}$ (Figure 3)

The diagnoses included were inveterate cervical luxation in two patients, congenital axial spondylolisthesis in one patient, congenital C1-C2 luxation (congenital hangman syndrome) in two patients, tumor in three patients, post-laminectomy kyphosis in one patient, post-infection kyphosis in one patient, fracture in one patient, syndromes with instabilities in 11 patients, and congenital scoliosis in five patients. (Table 1)

Neurological status was assessed using the Frankel scale. Of the 27 patients, 24 were evaluated as Frankel E, one as Frankel D, and two as Frankel C.

Arthrodesis was performed via transoral approach (two patients), isolated anterior approach (three patients), combined two-stage approach (two patients), and three-stage combined method approach (five patients).

In two cases where three-column osteotomy (VCR) needed to be performed, because of deficient bone quality, treatment was supplemented with the use of a halo-vest.

\section{RESULTS}

All of the patients evolved without complications of great relevance. The following were considered major complications related to the procedure: stenosis of the spinal canal, deep infection, osteomyelitis,

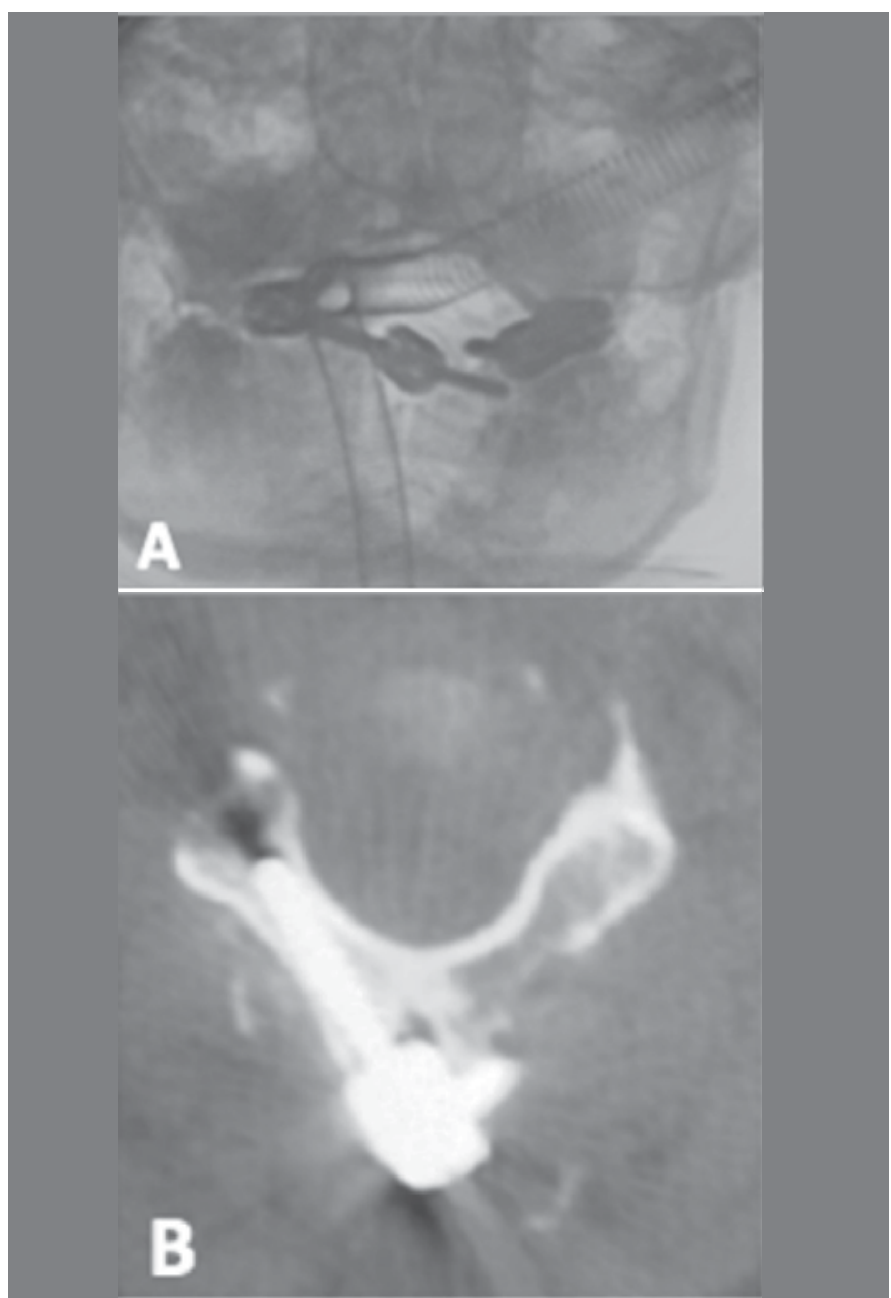

Figure 2. (A) Radiographic Image and (B) Post-operative tomography showing screw in the C2 lamina.

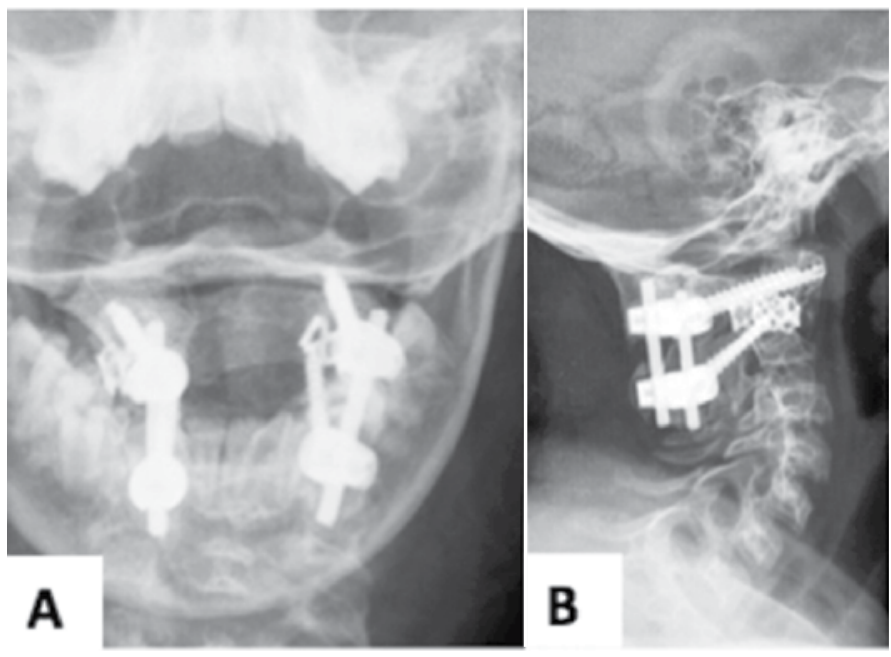

Figure 3. Postoperative AP $(A)$ and lateral $(B)$ radiographs showing mesh cage in the $\mathrm{C} 1-\mathrm{C} 2$ in the articular space for facet joint distraction.

limited range of motion for performing daily living activities, pseudoarthrosis, loss of correction, neurological deficit or worsening of preexisting deficit, and cervical pain. In our case series, complications were observed in four cases. Two patients had poor positioning of the $\mathrm{C} 1$ lateral mass screw. In one of the two cases, surgical revision was performed due to occipital neuralgia and in the other case a cervical collar was used until definitive consolidation, with posterior removal of the material. One patient had a cerebrospinal fluid fistula and the other a superficial infection of the surgical wound that was treated with antibiotics.

The radiographic and tomographic postoperative control exams did not exhibit any signs of loosening of the implant, loss of reduction, or signs of reabsorption indicating pseudoarthrosis.

Patients with clinical presentation of cervical pain from instability following stabilization and arthrodesis in the craniocervical joint obtained improved VAS scores without affecting the range of motion of the cervical spine. Patients with significant decompensation of coronal balance evolved with compensation after hemivertebra and tumor resection.

In the literature, many authors believe that rigid instrumentation should be used in 10-year-old children, whereas patients around three years old should be treated with sublaminar wires. ${ }^{12-14}$ Among the patients evaluated, the use of modern instrumentation was possible in two-year-old children.

Considering the final outpatient visit, all patients showed clinical and radiological improvement.

Only one patient with Morquio syndrome underwent surgery for screw repositioning because of $\mathrm{C} 1$ bone dysplasia.

Limitation of the range of cervical motion, a complication related to $\mathrm{C} 0-\mathrm{C} 1$ and $\mathrm{C} 1-\mathrm{C} 2$ arthrodesis, was not a relevant complaint in our patients, which we believe to be, in part, due to the patients' capacity for compensatory adaptation. ${ }^{15-17}$

\section{DISCUSSION}

Modern cervical instrumentation in pediatric patients continues to be a controversial topic. Fixation with pedicle screws was first described by Roy-Camille in 1970. He was the first to use these instrumentations in treating fractures. To date, there are no implants of a specific size for use in children. Among the techniques for cervical arthrodesis used in this population, the most frequently used is fixation with transarticular screws described by Margel.

As regards the anatomy of the cervical spine in pediatric patients, there are anatomical differences that make the instrumentation procedures complex and potentially subject to complications, considering the small size of the pedicles and lateral masses. ${ }^{18-20}$ 
Table 1. Patient demographic and surgical data.

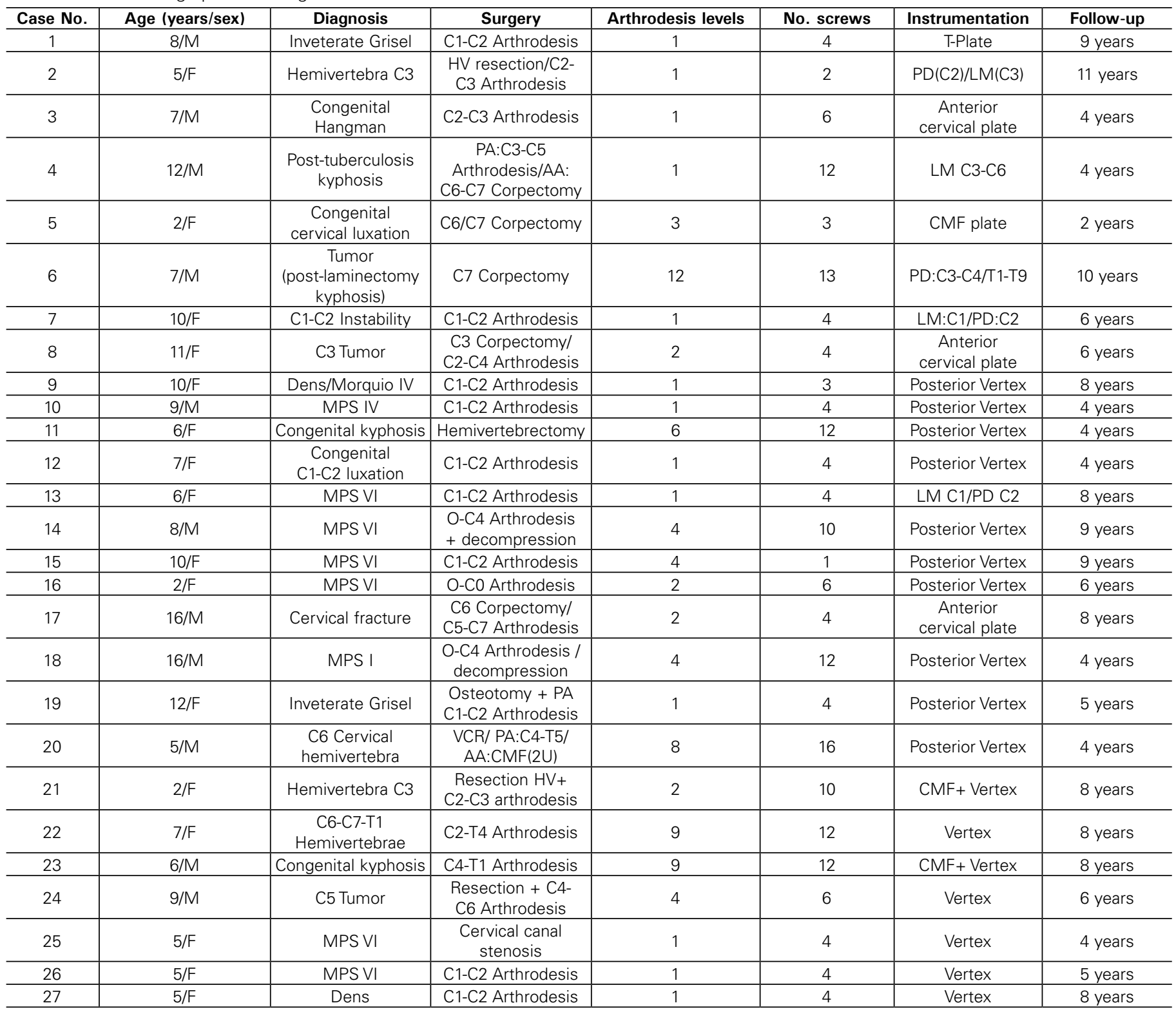

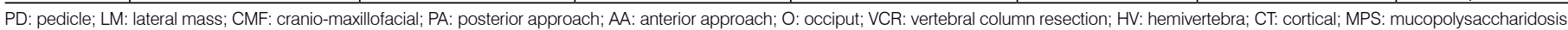

Treatment of cervical spine instability in children has traditionally been achieved with a combination of posterior wiring and orthosis with external halo techniques. ${ }^{21-23}$ In our study, we described techniques that can be applied in most of the different diseases that evolve with disability and that affect the cervical spine in patients with skeletal immaturity, helping to develop a flowchart that covers the appropriate type of instrumentation to be applied and anatomical considerations, in addition to customized techniques for each case.

The use of osteosynthesis with modern instrumentation was initiated in the services in question in 2007 and since that time, we have achieved better clinical results and higher fusion rates when compared to patients who previously underwent instrumentations such as rods and sublaminar wires. In spite of the technical and anatomical difficulties inherent in this class of patients, not only because of the reduced dimensions in those with normal anatomy, but also because of the dysplasias inherent in syndromic patients, our study proved that it is possible to use materials developed for adults in the study age group.

Instrumentation of the cervical spine in pediatric patients has been shown to be possible with greater safety with the evolution of imaging resources, such as computed tomography and magnetic resonance, the former being essential for the study of the bone anatomy and the course of the vertebral artery, thus being able to indicate the best technique and the appropriate implant for each case.

In our case series, we were able to show that, in general, implants of $3.5 \mathrm{~mm}$ are appropriate for use in the cervical spine of patients from two years of age. It was also possible, through postoperative follow-up and serial tomography studies to confirm that the use of this type of instrumentation in patients with open growth plates did not lead to the feared complications, such as stenosis of the spinal canal, considering that the dimension of the spinal canal are close to adult dimensions by around eight years of age. ${ }^{24}$

For stabilization and atlantoaxial stabilization, we performed instrumentation of the lateral mass of the atlas and of the pedicle of the axis, respecting the anatomical considerations presented above. It those patients if whom instrumentation of the $\mathrm{C} 2$ pedicle was not possible, we performed instrumentation of the lamina of $\mathrm{C} 2$, according to the technique described by Wright.

In our study, we used plates specially adapted for the reduced size of the vertebral body in two-year-old patients and, in the most recent procedures, instrumentation with anterior cervical plates was described for patients older than 12 years of age. This method 
was shown to be possible regardless of age, taking into account the disease being treated and the surgeon's experience with the local anatomy.

We also analyzed 118 of the 161 instrumented screws and we observed that all the screws were completely contained by bone. We also observed in follow-up assessments that the average age was 8.5 years and that all the patients treated had lower visual analog scale scores, suggesting clinical improvement, in addition to the absence of limitations in range of head motion. Tomographic studies also showed that none of the patients evolved with stenosis of the spinal canal.

\section{CONCLUSIONS}

Modern cervical instrumentation proved to be safe and effective in patients with skeletal immaturity, its use being recommended from two years of age, with high fusion rates and low complication rates, as long as a local anatomical study is conducted and the appropriate implant and technique are chosen in each case.

All authors declare no potential conflict of interest related to this article.

CONTRIBUTION OF THE AUTHORS: Each author made significant individual contributions to this manuscript. ASA, LECTS, and AGBC were the main contributors to the preparation of the manuscript. ASA, CDN, and GBLA participated in the surgical procedures as assistants and in outpatient follow-up, in addition to collecting clinical data and reviewing the medical records. LECTS and AGBC were the main surgeons in the cases and obtained per-, peri-, and postoperative clinical and radiological data. The idea for the manuscript was idealized by LECTS. ASA collected data from the medical records and wrote the manuscript. AGBC acted as co-advisor for the study, reviewed the literature, and corrected the article.

\section{REFERENCES}

1. Rajasekaran S, Kanna PR, Shetty TA. Intra-operative computer navigation guided cervical pedicle screw insertion in thirty-three complex cervical spine deformities. J Craniovertebr Junction Spine. 2010;1(1):38-43.

2. Ludwig SC, Kramer DL, Vaccaro AR, Albert TJ. Transpedicle screw fixation of the cervical spine. Clin Orthop Relat Res. 1999;(359):77-88.

3. Abumi K, Kaneda K. Pedicle screw fixation for nontraumatic lesions of the cervical spine. Spine (Phila Pa 1976). 1997 (16):1853-63.

4. Abumi $\mathrm{K}$, Itoh $\mathrm{H}$, Taneichi $\mathrm{H}$, Kaneda $\mathrm{K}$. Transpedicular screw fixation for traumatic lesions of the middle and lower cervical spine: description of the techniques and preliminary report. J Spinal Disord. 1994;7(1):19-28.

5. Esses SI, Sachs BL, Dreyzin V. Complications associated with the technique of pedicle screw fixation. A selected survey of ABS members. Spine (Phila Pa 1976). 1993:18(15):2231-8.

6. Yilmaz G, Demirkiran G, Ozkan C, Daglioglu K, Pekmezci M, Alanay A, et al. The effect of dilation of immature pedicles on pullout strength of the screws: Part 2: In vivo study. Spine (Phila Pa 1976). 2009:34(22):2378-83.

7. Anderson RC, Ragel BT, Mocco J, Bohman LE, Brockmeyer DL. Selection of a rigid inter nal fixation construct for stabilization at the craniovertebral junction in pediatric patients. J Neurosurg. 2007:107(1 Suppl):36-42.

8. Schultz KD Jr, Petronio J, Haid RW, Rodts GE, Erwood SC, Alexander J, et al. Pediatric occipitocervical arthrodesis. A review of current options and early evaluation of rigid internal fixation techniques. Pediatr Neurosurg. 2000;33(4):169-81

9. Wright NM. Posterior C2 fixation using bilateral, crossing C2 laminar screws: case series and technical note. J Spinal Disord Tech. 2004;17(2):158-62

10. Goel A. Treatment of basilar invagination by atlantoaxial joint distraction and direct lateral mass fixation. J Neurosurg Spine. 2004;1(3):281-6.

11. Narváez JA, Hernández-Gañán J, Isern J, Sánchez-Fernández JJ. Rheumatic diseases of the spine: imaging diagnosis. Radiologia. 2016;58 Suppl 1:35-49
12. Rahimi SY, Stevens EA, Yeh DJ, Flannery AM, Choudhri HF, Lee MR. Treatment of atlantoaxial instability in pediatric patients. Neurosurg Focus. 2003;15(6):ECP1.

13. Brockmeyer DL, Apfelbaum RI. A new occipitocervical fusion construct in pediatric patients with occipitocervical instability. Technical note. J Neurosurg. 1999;90(2 Suppl):271-5.

14. Jones EL, Heller JG, Silcox DH, Hutton WC. Cervical pedicle screws versus lateral mass screws. Anatomic feasibility and biomechanical comparison. Spine (Phila Pa 1976). 1997;22(9):977-82.

15. Wright NM. Posterior $C 2$ fixation using bilateral, crossing $C 2$ laminar screws: case series and technical note. J Spinal Disord Tech. 2004;17(2):158-62.

16. Abumi K, Takada T, Shono Y, Kaneda K, Fujiya M. Posterior occipitocervical reconstruction using cervical pedicle screws and plate-rod systems. Spine (Phila Pa 1976). 1999;24(14):1425-34

17. Goel A. Treatment of basilar invagination by atlantoaxial joint distraction and direct lateral mass fixation. J Neurosurg Spine. 2004;1(3):281-6.

18. Vaccaro AR, Betz RR, Zeidman SM, editors. Principles and practice of spine surgery. St. Louis: CV Mosby; 2003

19. Narváez JA, Hernández-Gañán J, Isern J, Sánchez-Fernández JJ. Rheumatic diseases of the spine: imaging diagnosis. Radiologia. 2016;58 Suppl 1:35-49

20. Hedequist $D$, Hresko T, Proctor M. Modern cervical spine instrumentation in children. Spine (Phila Pa 1976). 2008;33(4):379-83.

21. Letts M, Slutsky D. Occipitocervical arthrodesis in children. J Bone Joint Surg Am. 1990;72(8):1166-70.

22. Lowry DW, Pollack IF, Clyde B, Albright AL, Adelson PD. Upper cervical spine fusion in the pediatric population. J Neurosurg. 1997:87(5):671-6.

23. Schultz KD Jr, Petronio J, Haid RW, Rodts GE, Erwood SC, Alexander J, et al. Pediatric occipitocervical arthrodesis. A review of current options and early evaluation of rigid internal fixation techniques. Pediatr Neurosurg. 2000;33(4):169-81.

24. Ruf M, Harms J. Pedicle screws in 1- and 2-year-old children: technique, complications, and effect on further growth. Spine (Phila Pa 1976).2002;27(21):E460-6. 